\title{
Daya Dukung Sumberdaya Air dan Indeks Kekritisan Air Sub DAS Cisokan Hulu
}

\section{Water Carrying Capacity And Criticality Index Assessment On The Upper Cisokan Sub Watershed}

\author{
Dwi Rustam Kendarto ${ }^{\circledR}$, Edy Suryadi ${ }^{1}$, Rizky Mulya Sampurno ${ }^{1}$, Audi Putra \\ Cahyabhuana ${ }^{1}$ \\ ${ }^{1}$ Departemen Teknik Pertanian dan Biosistem, Fakultas Teknologi Industri Pertanian, Universitas Padjadjaran

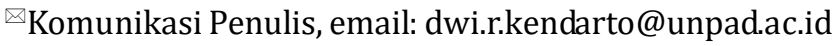 \\ DOI:http://dx.doi.org/10.23960/jtep-lv10i3.402-412
}

Naskah ini diterima pada 30 Agustus 2021; revisi pada 20 September 2021;

disetujui untuk dipublikasikan pada 23 September 2021

\begin{abstract}
Upper Cisokan sub-watershed is a natural ecosystem of water resource providers that can be used directly or indirectly by the community in it. The population rate and sectoral needs in the area are estimated have put pressure to the water balance. The value of the water carrying capacity and the water criticality are known from the water balance analysis. The availability of water resources (Wn) was determined based on the flow rate probability (Q80) of Weibull Method, the value of groundwater, springs and wells, and also the raw water supply of the local water company. Water demand (qpt) estimated based on the Statistic data, industrial data, agricultural area data, livestock production data, and fishery area data. The water carrying capacity $(\mathrm{Cw})$ is generally still adequate (High), but at June to November, the water carrying capacity status shows a value of 1.84 (Critical) to 0.24 (Deficit). In general, the water criticality index is still safe (Not Critical), but in the dry period, especially in July, August and November, it shows a value of $125 \%$ to $421 \%$ (Very Critical). To anticipate the water crisis, stakeholders should allocate water efficiently according to its availability. So that the ecosystem is sustainably provide ecosystem services for providing water resources to the community.
\end{abstract}

Key words : ecosystem services, upper Cisokan Sub watershed, water balance, water resources carrying capacity, water criticality index

\begin{abstract}
ABSTRAK
Sub DAS Cisokan Hulu merupakan ekosistem alami penyedia layanan sumberdaya air yang dapat dimanfaatkan secara langsung maupun tidak langsung oleh masyarakat di dalamnya. Laju penduduk dan kebutuhan sektoral pada suatu wilayah Sub DAS diperkirakan mempengaruhi kesetimbangan antara ketersediaan dan kebutuhan air. Nilai status daya dukung dan indeks kekritisan air diketahui dari analisis neraca air. Ketersediaan air (Wn) diperoleh berdasarkan analisis debit andalan Q80\% Metode Weibull, pendugaan cadangan air tanah, mata air dan sumur, serta suplai air baku melalui PDAM. Kebutuhan air (qp(t)) diduga berdasarkan jumlah penduduk dalam wilayah sub DAS beserta proyeksinya pada tahun 2030, data sektor industri, data luasan areal pertanian, data produksi ternak dan data luasan areal perikanan. Status daya dukung sumberdaya air (Cw) Sub DAS Cisokan Hulu secara umum masih memadai (Tinggi), namun pada puncak kemarau yaitu Juni hingga November status daya dukung air menunjukkan nilai 1,84 (Kritis) hingga 0,24 (Defisit). Indeks kekritisan air secara umum masih aman (Belum Kritis), namun pada periode kemarau khususnya bulan Juli, Agustus, dan November menunjukkan nilai $125 \%$ hingga $421 \%$ (Sangat Kritis). Untuk mengantisipasi krisis air, sebaiknya seluruh stakeholder mengalokasikan kebutuhan air secara efisien sesuai dengan ketersediaannya. Sehingga ekosistem Sub DAS Cisokan Hulu mampu berkelanjutan memberikan jasa ekosistem penyediaan sumberdaya air kepada masyarakat.
\end{abstract}

Kata kunci : indeks kekritisan air, jasa ekosistem, neraca air, status daya dukung sumberdaya air, sub DAS Cisokan hulu 


\section{PENDAHULUAN}

Sebagai suatu wilayah tangkapan air, Daerah Aliran Sungai (DAS) memberikan pengaruh besar terhadap ketersediaan air di suatu daerah. DAS merupakan ekosistem alami penyedia layanan sumberdaya air permukaan yang secara langsung maupun tidak langsung dimanfaatkan oleh makhluk hidup di dalamnya. Jawa Barat merupakan salah satu kawasan dengan pemanfaatan sumberdaya air yang tinggi. Menurut Badan Pusat Statisik, laju pertumbuhan penduduk Jawa Barat pada tahun 2020 sebesar $1,26 \%$ dengan jumlah penduduk di tahun yang sama sebanyak 49.935.858 jiwa. Daerah dengan pertumbuhan pesat tersebut dominan berada pada kawasan Daerah Aliran Sungai Citarum. Sub DAS Cisokan Hulu masuk ke dalam wilayah hulu dari DAS Citarum. Terdapat tiga kecamatan di Kabupaten Bandung Barat yang masuk dalam cakupan wilayah Sub DAS Cisokan Hulu, yaitu Kecamatan Rongga, Gununghalu dan Sindangkerta. Sub DAS ini berperan penting sebagai daerah tangkapan air, sedangkan aliran sungai Cisokan dimanfaatkan sebagai sumber pengelolaan air atau penyedia layanan jasa ekosistem sumberdaya air.

Sesuai dengan penelitian Nurrochmad pada tahun 2003 mengenai optimasi pemanfaatan air irigasi Bendung Cisokan, menunjukkan bahwa pada musim kemarau telah menyebabkan sebagian areal irigasi tidak memperoleh air. Ketersediaan air bendung Cisokan relatif besar pada periode Januari hingga Mei dengan debit tertinggi sebesar $15,30 \mathrm{~m}^{3} / \mathrm{s}$ pada bulan Januari. Sedangkan ketersediaan air relatif kecil pada periode Juni hingga September, dengan debit minimal sebesar $0,83 \mathrm{~m}^{3} / \mathrm{s}$ pada bulan Juni (Nurrochmad, 2003). Penurunan produksi air juga diperparah oleh tidak teraturnya pola curah hujan yang turun di dalam DAS. Terutama yang berkaitan dengan durasi antara bulan basah dan kering yang tidak imbang sebagai akibat dari pemanasan global. Terjadinya kasus penurunan produksi sumberdaya air, diprediksi akan menjadi sumber permasalahan yang serius. Permasalahan sumberdaya air yang paling signifikan terjadi yaitu adanya gejala krisis air, degradasi sumberdaya air, konflik akibat persaingan antar pengguna air yang semakin tajam, alih fungsi lahan pertanian beririgasi, kurang jelasnya ketentuan hak pengusahaan air serta lemahnya koordinasi antar instansi yang menangani sumberdaya air (Rejekiningrum, 2014).

Sub DAS Cisokan Hulu dengan luasan sekitar $74.563 \mathrm{Ha}$ ini menjadi kunci penyedia sumberdaya air baik itu untuk domestik, industri dan pertanian di dalamnya. Eksploitasi akibat peningkatan jumlah penduduk, industri dan pembangunan infrastruktur dikhawatirkan menjadi ancaman yaitu terjadinya potensi krisis akibat in-efisiensi pemanfaatan sumberdaya air. Nilai ketersediaan air suatu wilayah dapat diketahui melalui analisis neraca air. Sebagai upaya mengetahui kondisi sumberdaya air, maka dilakukan penelitian terhadap status daya dukung sumberdaya air serta nilai indeks kekritisan air berbasis neraca keseimbangan antara ketersediaan dan kebutuhan air Sub DAS Cisokan Hulu. Tujuan penelitian ini dilakukan untuk mengetahui status daya dukung sumberdaya air dan indeks kekritisan air pada kondisi eksisting pada tahun 2020 dan prediksinya pada 10 tahun mendatang.

\section{BAHAN DAN METODE}

Penelitian ini dilaksanakan di Sub DAS Cisokan Hulu, Kabupaten Bandung Barat pada bulan Juni sampai Agustus 2021. Alat yang digunakan dalam penelitian ini adalah komputer dengan kelengkapan software ArcGIS 10.3, CROPWAT 8.0, Ms. Word, Ms. Excel, dan kalkulator saintifik. Bahan yang digunakan dalam penelitian adalah data debit bulanan Sungai Cisokan (2001-2020), data klimatologi (2001-2020), data produksi air baku PDAM, data ketersediaan debit mata air dan sumur resapan Sub DAS Cisokan Hulu, data kependudukan Sub DAS Cisokan Hulu BPS Kab. Bandung Barat, data jumlah industri, data luasan areal pertanian, data produksi ternak, data sektor perikanan, Peta Administrasi Sub DAS Cisokan Hulu, Peta Hidrogeologi Jawa Barat dan Peta Penggunaan Lahan Sub DAS Cisokan Hulu. Data klimatologi meliputi data suhu, lama penyinaran, kecepatan angin. Staiun hujan menggunakan stasiun Klimatologi Bandung karena tidak terdapat stasiun hujan yang memadai di sekitar wilayah penelitian. 
Penelitian dilakukan secara deskriptif melalui analisis ketersediaan air, analisis kebutuhan air, analisis neraca air hingga penentuan status daya dukung sumberdaya air dan indeks kekritisan air Sub DAS Cisokan Hulu. Wilayah penelitian ini tertera dalam Peta Administrasi dalam Gambar 1.

\subsection{Analisis Ketersediaan Air}

Ketersediaan air merupakan jumlah air (debit) yang diperkirakan secara terus menerus ada dalam sungai dan air hujan yang jatuh dalam dengan periode tertentu. Ketersediaan air dinyatakan dengan hasil perhitungan rata-rata dalam satuan waktu tertentu atau hasil perhitungan debit andalan yang dihubungkan dengan probabilitas tertentu. Pola ketersediaan air di sebagian besar wilayah, bergantung pada pola curah hujan, nilai debit sungai dan tatanan hidrologi pada wilayah tersebut. Ketersediaan air tanah merupakan salah satu sumber ketersediaan air selain tersedianya air meteorologis.

Potensi air tanah di suatu cekungan tidak terlepas dari kondisi hidrogeologi di wilayah itu sendiri. Seiring dengan waktu geologi, aliran air tanah melalui lapisan batuan penyusun akuifer akan menyebabkan berbagai proses yang memengaruhi dinamika air tanah itu sendiri (Kodoatie, 1996). Sumber air tanah pada suatu akuifer dalam suatu DAS diasumsikan berasal dari air hujan yang mengalami infiltrasi kemudian menjadi aliran air tanah dari bagian hulu menuju ke hilir. Ketersediaan air tanah sangatlah unik dan spesifik, terkadang tidak menyebar secara merata sehingga untuk mengetahuinya perlu dilakukan penyelidikan geologi bawah permukaan (Waspodo, 2015).

Berdasarkan SNI 6738:2015 (BSN, 2015), penggambaran ketersediaan air di Indonesia pada lokasi sungai biasanya menggunakan probabilitas $80 \%$, 90\% dan 95\%. Secara umum untuk irigasi digunakan probabilitas $80 \%$. Dapat diartikan sebagai probabilitas terjadinya debit yang lebih besar dari yang direncanakan. Peruntukan lainnya seperti debit andalan 90\% digunakan untuk air baku dan PLTA, sedangkan 95\% untuk aliran pemeliharaan sungai. Tingkat keandalan debit dihitung berdasarkan nilai probabilitas kejadian mengikuti rumus Weibull sebagai berikut (BSN, 2015):

$$
P=\frac{m}{n+1} \times 100 \%
$$

dimana $\mathrm{P}$ adalah probabilitas terjadinya nilai yang diharapkan selama periode pengamatan (\%), m adalah peringkat data, dan $\mathrm{n}$ adalah jumlah data.

\subsection{Kebutuhan Air}

Air yang tersedia pada wilayah Sub DAS dapat dimanfaatkan secara langsung maupun tidak langsung untuk berbagai kebutuhan, seperti untuk keperluan domestik, industri, pertanian, peternakan dan perikanan. Jumlah konsumsi air diperkirakan berdasarkan jumlah pemakai dan penyesuaian atas standar kebutuhan masingmasing sektoral.

\subsubsection{Kebutuhan Air Penduduk}

Kebutuhan air penduduk adalah kebutuhan air untuk memenuhi kebutuhan hidup manusia

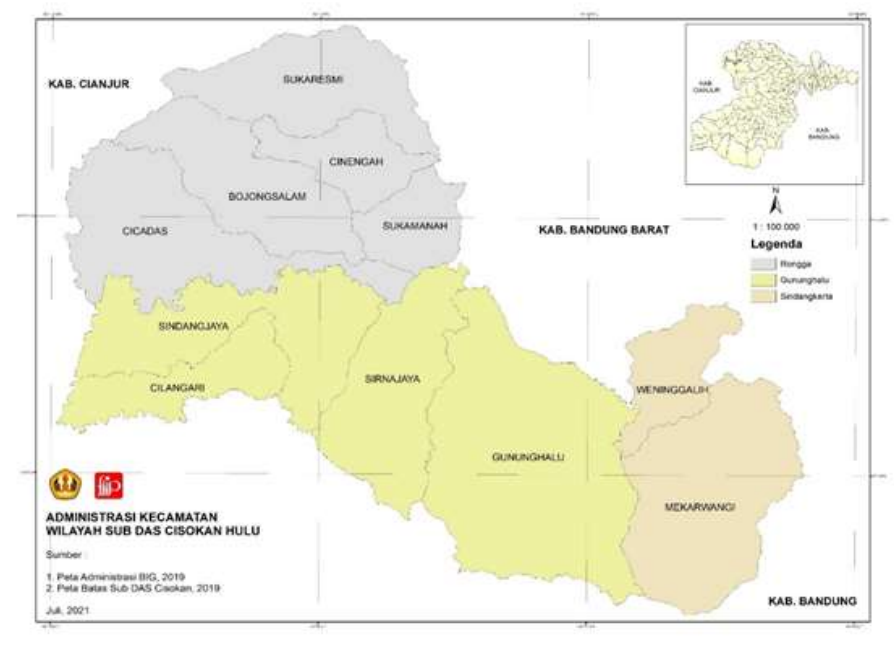

Gambar 1. Peta Administrasi Sub DAS Cisokan Hulu 
sehari-hari (BPPN, 2006). Kebutuhan air domestik dihitung berdasarkan jumlah penduduk yang ada di Kabupaten Bandung Barat dan mengalikannya dengan standar kebutuhan air ditentukan berdasarkan jumlah penduduk dalam tiap kecamatan di lingkup Sub DAS Cisokan Hulu, disesuaikan dengan standar yang tercantum dalam Tabel 1.

\subsubsection{Prediksi Kebutuhan Air Penduduk 2030}

Untuk memprediksi status daya dukung sumberdaya air dan indeks kekritisan air pada tahun 2030 maka dilakukan prediksi terhadap jumlah penduduk Sub DAS Cisokan Hulu. Proyeksi jumlah penduduk dilakukan dengan metode geometri (BPS, 2012):

$$
P n=P o(1+r)^{n-o}
$$

dimana Pn adalah jumlah penduduk pada tahun n (tahun ditanyakan), Po adalah jumlah penduduk pada tahun o (tahun dasar/diketahui), 1 adalah konstanta, $r$ adalah persentase pertumbuhan penduduk per tahun, dan n-o adalah selisih tahun o dengan tahun $n$.

\subsubsection{Kebutuhan Air Industri}

Kebutuhan air industri dihitung berdasarkan jumlah masing-masing industri (besar, sedang, kecil) yang ada di Kabupaten Bandung Barat dan mengalikannya dengan standar kebutuhan air (ditentukan berdasarkan kategori industri dalam Kabupaten Bandung Barat). Untuk menentukan kebutuhan air bersih untuk industri pertanian dapat dikategorikan menjadi tiga jenis, masingmasing untuk industri besar berkisar 151 - 350 $\mathrm{m}^{3}$ /hari, industri sedang berkisar $51-150 \mathrm{~m}^{3}$ / hari, industri kecil berkisar $5-50 \mathrm{~m}^{3} /$ hari dan industri menengah sebesar $4 \mathrm{~m}^{3} /$ hari (Purwanto, 1995).

\subsubsection{Kebutuhan Air Pertanian}

Perhitungan kebutuhan air pada penelitian ini menggunakan aplikasi CROPWAT 8.0. CROPWAT merupakan decision support system application yang dikembangkan oleh Divisi Land and Water Development FAO berdasarkan metode Penman-Monteith, untuk merencanakan dan mengatur irigasi pertanian. Input dalam CROPWAT meliputi data meteorologi, tanah, dan tanaman. Aplikasi ini dapat dimanfaatkan untuk menghitung evapotranspirasi potensial, evapotranspirasi aktual, kebutuhan air irigasi satu jenis tanaman maupun beberapa jenis tanaman dalam satu masa tanam, serta merencanakan pemberian air irigasi. Dari beberapa studi didapatkan bahwa model Penmann-Monteith memberikan pendugaan yang akurat sehingga FAO merekomendasikan penggunaannya untuk pendugaan laju evapotranspirasi standar dalam perhitungan kebutuhan air bagi tanaman. Data yang diperlukan untuk mengoperasikan CROPWAT adalah data klimatologi bulanan (temperatur maksimum-minimum atau ratarata, penyinaran matahari, kelembaban, kecepatan angin dan curah hujan). Data tanaman tersedia dalam program secara terbatas dan dapat ditambahkan atau dimodifikasi sesuai dengan kondisi setempat (Tumiar, et al.. 2012).

\subsubsection{Kebutuhan Air Peternakan}

Berdasarkan SNI 6728.1-2015, perhitungan kebutuhan air rata-rata untuk peternakan tergantung pada populasi atau jumlah ternak dan jenis ternak. Besar kebutuhan air untuk ternak ditampilkan pada Tabel 2. Umumnya kebutuhan air peternakan diestimasikan dengan cara mengalikan jumlah ternak dengan tingkat kebutuhan air berdasarkan persamaan berikut (BSN, 2015):

Tabel 1. Standar Kebutuhan Air Penduduk

\begin{tabular}{ccc}
\hline $\begin{array}{c}\text { Jumlah Penduduk } \\
\text { (jiwa) }\end{array}$ & Kategori Kota & $\begin{array}{c}\text { Kebutuhan Air } \\
\text { (L/orang/hari) }\end{array}$ \\
\hline$>2.000 .000$ & Metropolitan & $>210$ \\
$1.000 .000-2.000 .000$ & Metropolitan & $150-210$ \\
$500.000-1.000 .000$ & Besar & $120-150$ \\
$100.000-500.000$ & Besar & $100-150$ \\
$20.000-100.000$ & Kecil & $90-100$ \\
$3.000-20.000$ & Kecil & $60-100$ \\
\hline
\end{tabular}

Sumber: SNI, 2015 


$$
Q e=\left(q_{(1)} \times P_{(1)}+q_{(2)} \times P_{(2)}+q_{(3)} \times P_{(3)}\right)
$$

dimana Qe adalah kebutuhan air untuk ternak (L/hari), $\mathrm{q}_{(1)}$ adalah kebutuhan air untuk sapi, kerbau dan kuda (L/ekor/hari), $\mathrm{q}_{(2)}$ adalah kebutuhan air untuk kambing dan domba (L/ ekor/hari), $\mathrm{q}_{(3)}$ adalah kebutuhan air untuk unggas (L/ekor/hari), $\mathrm{P}_{(1)}$ adalah jumlah sapi, kerbau dan kuda (ekor), $\mathrm{P}_{(2)}$ adalah jumlah kambing dan domba (ekor), dan $\mathrm{P}_{(3)}$ adalah jumlah unggas (ekor).

\subsubsection{Kebutuhan Air Perikanan}

Kebutuhan air untuk komoditas perikanan diperkirakan berdasarkan pendekatan atas luas kolam, tipe kolam dan kedalaman air yang diperlukan. Kebutuhan ini meliputi volume untuk pengisian kolam pada saat awal tanam dan penggantian air. Debit air yang optimal untuk kolam perikanan diasumsikan berkisar antara 10-15 L/s/ha. Sedangkan air untuk kebutuhan pembilasan merupakan $1 / 3$ dari debit optimal pada kolam (Novita et al., 2020). Umumnya kebutuhan air perikanan diestimasikan berdasarkan persamaan berikut:

$$
Q f p=q f p \times A f p
$$

dimana Qfp adalah kebutuhan air perikanan $\left(\mathrm{m}^{3} /\right.$ s), Qfp adalah kebutuhan air pembilasan, sebesar 1/3 debit optimal kolam (5 L/s/ha), dan Afp adalah luas kolam (ha).

\subsection{Status Daya Dukung Sumberdaya Air}

Evaluasi keadaan (status) daya dukung sumberdaya air berdasarkan analisis keseimbangan air antara supply dan demand. Perhitungan dilakukan dengan mode twin pointer (Narulita dan Djuwansyah, 2018). Besaran daya dukung sumberdaya air $(\mathrm{Cw})$ dapat diklasifikasikan berdasarkan nilai perbandingan ketersediaan dan kebutuhan dalam Tabel 3. Pada model ini, status daya dukung sumberdaya air $(\mathrm{Cw})$ diukur dengan persamaan :

$$
C w=W n / q p(t)
$$

dimana Wn adalah ketersediaan air $\left(\mathrm{m}^{3} / \mathrm{s}\right)$ dan $\mathrm{qp}(\mathrm{t})$ adalah permintaan atau konsumsi air pada satuan waktu tertentu $\left(\mathrm{m}^{3} / \mathrm{s}\right)$.

\subsection{Indeks Kekritisan Air}

Tingkat kekritisan air diketahui dari perbandingan jumlah kebutuhan air total dengan jumlah ketersediaan air. Ketersediaan air didapatkan dari jumlah ketersediaaan air meteorologis, air hidrologis dan air tanah. Jumlah kebutuhan air di DAS Cisokan merupakan total jumlah kebutuhan air domestik, air industri, air irigasi, perikanan dan peternakan. Klasifikasi indeks kekritisan air adalah seperti yang disajikan dalam Tabel 4.

Tabel 2. Kebutuhan Air Peternakan

\begin{tabular}{lc}
\hline Jenis Ternak & Kebutuhan air (L/ekor/hari) \\
\hline Sapi/kerbau/kuda & 40 \\
Kambing/domba & 5 \\
Babi & 6 \\
Unggas & 0,6 \\
\hline
\end{tabular}

Sumber: SNI, 2015

Tabel 3. Klasifikasi Status Daya Dukung Sumberdaya Air

\begin{tabular}{cc}
\hline Kelas Daya Dukung Sumberdaya Air & Nilai Cw \\
\hline Defisit & $<1$ \\
Kritis & $1-2$ \\
Mencukupi & $2-8$ \\
Sedang/ leluasa & $8-64$ \\
Tinggi/ berlebih & $64-256$ \\
Sangat tinggi/ berlimpah & $>256$ \\
\hline
\end{tabular}

Sumber: Narulita dan Djuwansah, 2018 


\section{HASIL DAN PEMBAHASAN}

\subsection{Analisis Ketersediaan Air}

Berdasarkan data-data dan analisis yang telah dihimpun, nilai ketersediaan air Sub DAS Cisokan Hulu meliputi wilayah Kecamatan Rongga, Gununghalu dan Sindangkerta, disajikan dalam Tabel 5. Ketersediaan total sumberdaya air (Wn) untuk tahun alokasi 2020 sebesar $104,81 \mathrm{~m}^{3} / \mathrm{s}$. Nilai tersebut disajikan secara rinci sesuai dengan kondisi ketersediaan pada tiap bulannya. Berdasarkan debit andalan 80\% analisis Weibull, ketersediaan air dari aliran Sungai Cisokan sebesar 104,72 $\mathrm{m}^{3} / \mathrm{s}$ Sebagai catatan informasi penting, bulan Februari merupakan puncak debit di musim penghujan sebesar $18,84 \mathrm{~m}^{3} / \mathrm{s}$. Sedangkan debit terendah di 2020 tercatat pada bulan Agustus senilai 0,84 $\mathrm{m}^{3} / \mathrm{s}$. Ketersediaan sumberdaya air yang minim pada musim kemarau, dikhawatirkan menjadi kendala dalam kesimbangan antara ketersediaan dan kebutuhan.

Ketersediaan sumberdaya air alternatif selain debit sungai yaitu, nilai debit produksi air baku dari PDAM Tirta Raharja IPA Cililin, merupakan debit yang diketahui produksi nya dalam satu tahun yang dikonversikan ke satuan $\mathrm{m}^{3} / \mathrm{s}$. Sehingga diasumsikan konsumsi air oleh masyarakat Sub DAS ini dalam satu bulannya dalam kisaran maksimal yang sama yaitu 0,02 $\mathrm{m}^{3} / \mathrm{s}$. Asumsi yang sama juga dilakukan pada sumber ketersediaan sumberdaya air melalui mata air dan sumur-sumur warga sebesar masing-masing 0,06 dan $0,005 \mathrm{~m}^{3} / \mathrm{s}$.

\subsection{Analisis Kebutuhan Air}

Berdasarkan pengumpulan data dan hasil analisis, diketahui nilai kebutuhan air tiap sektor dalam Sub DAS Cisokan Hulu tahun alokasi 2020 seperti pada Tabel 6. Konsumsi air total (qp(t)) tahun alokasi 2020 Sub DAS Cisokan Hulu menunjukkan bahwa pada wilayah ini, pemakaian air dominan untuk irigasi pertanian yang mencakup 6233 ha areal lahan padi dan palawija sebesar $21,33 \mathrm{~m}^{3} / \mathrm{s}$. Pemakaian domestik masyarakat hanya sebesar $0,14 \mathrm{~m}^{3} / \mathrm{s}$. Bahkan kebutuhan air industri dan perikanan menunjukkan nilai yang relatif sama besar, 0,02 $\mathrm{m}^{3} / \mathrm{s}$. Kebutuhan air peternakan menjadi sektoral dengan konsumsi paling minim yaitu $0,01 \mathrm{~m}^{3} / \mathrm{s}$.

Konsumsi air total (qp(t)) untuk prediksi tahun alokasi 2030 Sub DAS Cisokan Hulu (Tabel 7) berdasarkan fokus pada proyeksi laju pertumbuhan penduduk menunjukkan bahwa pada wilayah ini, pemakaian air masih dominan untuk irigasi pertanian yang mencakup 6233 ha areal lahan padi dan palawija yaitu sebanyak $21,33 \mathrm{~m}^{3} / \mathrm{s}$. Pemakaian domestik masyarakat diprediksikan hanya meningkat $0,02 \mathrm{~m}^{3} / \mathrm{s}$ dari

Tabel 4. Klasifikasi Indeks Kekritisan Air

\begin{tabular}{cc}
\hline Indeks Kekritisan Air & Klasifikasi \\
\hline $0-25 \%$ & Belum Kritis \\
$25-50 \%$ & Mendekati Kritis \\
$50-75 \%$ & Agak Kritis \\
$75-100 \%$ & Kritis \\
$>100 \%$ & Sangat Kritis \\
\hline
\end{tabular}

Sumber : Hatmoko et al., 2012

Tabel 5. Ketersediaan Air Total Sub DAS Cisokan Hulu 2020

\begin{tabular}{|c|c|c|c|c|c|c|c|c|c|c|c|c|c|}
\hline \multirow{2}{*}{ Kondisi } & \multirow{2}{*}{$\begin{array}{c}\text { Jumlah } \\
\text { Tahunan }\end{array}$} & \multicolumn{12}{|c|}{ Debit Wn Bulanan $2020\left(\mathrm{~m}^{3} / \mathrm{s}\right)$} \\
\hline & & Jan & Feb & Mar & Apr & Mei & Jun & Jul & Ags & Sep & Okt & Nov & Des \\
\hline Q80 & 104,72 & 12,84 & 18,84 & 15,54 & 15,40 & 10,68 & 4,40 & 1,32 & 0,84 & 0,60 & 2,90 & 8,64 & 12,72 \\
\hline PDAM & 0,02 & 0,02 & 0,02 & 0,02 & 0,02 & 0,02 & 0,02 & 0,02 & 0,02 & 0,02 & 0,02 & 0,02 & 0,02 \\
\hline Mata air & 0,06 & 0,06 & 0,06 & 0,06 & 0,06 & 0,06 & 0,06 & 0,06 & 0,06 & 0,06 & 0,06 & 0,06 & 0,06 \\
\hline Sumur & 0,005 & 0,005 & 0,005 & 0,005 & 0,005 & 0,005 & 0,005 & 0,005 & 0,005 & 0,005 & 0,005 & 0,005 & 0,005 \\
\hline $\begin{array}{l}\text { Total } \\
\left(\mathrm{m}^{3} / \mathrm{s}\right)\end{array}$ & 1 & 12,93 & 3 & 15,63 & 15,49 & 10,77 & 4,49 & 1 & 0,93 & 0,69 & 2,99 & 8,73 & 12,81 \\
\hline
\end{tabular}

Sumber: Hasil Analisis, 2021 
$0,14 \mathrm{~m}^{3} / \mathrm{s}$ menjadi $0,16 \mathrm{~m}^{3} / \mathrm{s}$. Bahkan kebutuhan air industri dan perikanan menunjukkan nilai yang relatif sama besar, $0,02 \mathrm{~m}^{3} / \mathrm{s}$. Kebutuhan air peternakan menjadi sektoral dengan konsumsi paling minim, dengan nilai kebutuhan sebesar $0,01 \mathrm{~m}^{3} / \mathrm{s}$.

\subsection{Neraca Air Sub DAS Cisokan Hulu}

Konsep siklus hidrologi bahwa jumlah air di suatu luasan tertentu di permukaan bumi dipengaruhi oleh besarnya air yang masuk (input) dan keluar (output) pada jangka waktu tertentu. Semakin cepat siklus hidrologi terjadi maka tingkat neraca air nya semakin dinamis. Berdasarkan nilai ketersediaan dan kebutuhan air tahun 2020 maupun proyeksi 2030, menampilkan output neraca keseimbangan sumberdaya air yang dominan surplus. Kedua data output memberikan gambaran bahwa karakteristik hidrologi wilayah Sub DAS Cisokan Hulu ini masih mampu memberikan support terhadap jasa ekosistem penyediaan sumberdaya air. Namun perlu diperhatikan, khususnya pada kejadian puncak defisit air di bulan-bulan kering yaitu Juli, Agustus dan November. Nilai ketersediaan ini dapat dijadikan acuan para stakeholder untuk membuat perencanaan yang tepat dan sesuai, agar tidak timbul adanya permasalahan akibat krisis air pada bulan-bulan kering. Tren neraca air dapat dilihat dalam Gambar 2.
Kebutuhan air untuk tahun 2020 dan proyeksi di 2030, tidak ada perbedaan yang signifikan. Prediksi kebutuhan yang didasari proyeksi peningkatan laju penduduk hanya memberikan beban pada ketersediaan air dengan nilai 0,02 $\mathrm{m}^{3} / \mathrm{s}$ lebih besar dari kebutuhan eksisting 2020 . Maka pada Gambar 2, garis antara kedua tahun tersebut secara sekilas bertumpuk pada tren yang sama dan tidak nampak adanya perbedaan. Ketersediaan air yang melimpah pada musim penghujan, diharapkan mampu dimanfaatkan dengan tepat untuk mengantisipasi krisis sumberdaya air pada musim kemarau.

Sesuai dengan karakteristik hidrogeologi sub DAS Cisokan Hulu, dominasi kelulusan air adalah rendah hingga sedang. Waktu singgah air yang jatuh menjadi limpasan sangat sedikit termanfaatkan, kecuali air yang mampu terinfiltrasi ke dalam tanah. Air terinfiltrasi ini akan tinggal lebih lama sebagai air tanah dangkal, dengan asumsi pada Sub DAS ini, air tersebut akan keluar kembali mengisi aliran sungai dan juga beberapa menjadi baseflow. Pada periode hujan yang tinggi, pengisian air tanah dangkal akan terus menerus dengan disertai lolosan ke arah aliran sungai, sehingga muka air tanah atau muka air pada sumur akan menjadi tinggi. Namun pada saat hujan tidak turun pada periode yang cukup lama dengan puncaknya pada Juli, Agustus, dan September hanya berkisar 0,7 - 1,4 $\mathrm{m}^{3} / \mathrm{s}$

Tabel 6. Rincian Kebutuhan Air Total Sub DAS Cisokan Hulu 2020

\begin{tabular}{|c|c|c|c|c|c|c|c|c|c|c|c|c|c|}
\hline \multirow{2}{*}{ Kondisi } & \multirow{2}{*}{$\begin{array}{l}\text { Jumlah } \\
\text { Tahunan }\end{array}$} & \multicolumn{12}{|c|}{ Debit qp(t) Bulanan $\left(\mathrm{m}^{3} / \mathrm{s}\right)$} \\
\hline & & Jan & Feb & Mar & Apr & Mei & Jun & Jul & Ags & Sep & 0kt & Nov & Des \\
\hline Domestik & 0,14 & 0,14 & 0,14 & 0,14 & 0,14 & 0,14 & 0,14 & 0,14 & 0,14 & 0,14 & 0,14 & 0,14 & 0,14 \\
\hline Industri & 0,02 & 0,02 & 0,02 & 0,02 & 0,02 & 0,02 & 0,02 & 0,02 & 0,02 & 0,02 & 0,02 & 0,02 & 0,02 \\
\hline Irigasi & 21,33 & 0,00 & 0,07 & 0,00 & 0,00 & 0,00 & 2,23 & 5,71 & 2,42 & 0,23 & 0,00 & 10,66 & 0,01 \\
\hline Peternakan & 0,01 & 0,01 & 0,01 & 0,01 & 0,01 & 0,01 & 0,01 & 0,01 & 0,01 & 0,01 & 0,01 & 0,01 & 0,01 \\
\hline Perikanan & 0,02 & 0,02 & 0,02 & 0,02 & 0,02 & 0,02 & 0,02 & 0,02 & 0,02 & 0,02 & 0,02 & 0,02 & 0,02 \\
\hline Total $\left(\mathrm{m}^{3} / \mathrm{s}\right)$ & 21,52 & 0,19 & 0,26 & 0,19 & 0,19 & 0,19 & 2,42 & 5,90 & 2,61 & 0,42 & 0,19 & 10,85 & 0,20 \\
\hline
\end{tabular}

Sumber: Hasil Analisis, 2021

Tabel 7. Rincian Prediksi Kebutuhan Air Total Sub DAS Cisokan Hulu 2030

\begin{tabular}{|c|c|c|c|c|c|c|c|c|c|c|c|c|c|}
\hline \multirow{2}{*}{ Kondisi } & \multirow{2}{*}{$\begin{array}{l}\text { Jumlah } \\
\text { Tahunan }\end{array}$} & \multicolumn{12}{|c|}{ Debit qp(t) Bulanan $\left(\mathrm{m}^{3} / \mathrm{s}\right)$} \\
\hline & & Jan & Feb & Mar & Apr & Mei & Jun & Jul & Ags & Sep & Okt & Nov & Des \\
\hline Domestik & 0,16 & 0,16 & 0,16 & 0,16 & 0,16 & 0,16 & 0,16 & 0,16 & 0,16 & 0.16 & 0,16 & 0,16 & 0,16 \\
\hline Industri & 0,02 & 0,02 & 0,02 & 0,02 & 0,02 & 0,02 & 0,02 & 0,02 & 0,02 & 0.02 & 0,02 & 0,02 & 0,02 \\
\hline Irigasi & 21,33 & 0,00 & 0,07 & 0,00 & 0,00 & 0,00 & 2,23 & 5,71 & 2,42 & 0.23 & 0,00 & 10,66 & 0,01 \\
\hline Peternakan & 0,01 & 0,01 & 0,01 & 0,01 & 0,01 & 0,01 & 0,01 & 0,01 & 0,01 & 0.01 & 0,01 & 0,01 & 0,01 \\
\hline Perikanan & 0,02 & 0,02 & 0,02 & 0,02 & 0,02 & 0,02 & 0,02 & 0,02 & 0,02 & 0.02 & 0,02 & 0,02 & 0,02 \\
\hline Total & 21,54 & 0,21 & 0,28 & 0,21 & 0,21 & 0,21 & 2,44 & 5,92 & 2,63 & 0.44 & 0,21 & 10,87 & 0,22 \\
\hline
\end{tabular}

Sumber: Hasil Analisis, 2021 
maka muka air tanah akan menurun drastis dan tidak dapat dimanfaatkan. Sesuai dengan karakteristik hidrogeologi Sub DAS Cisokan Hulu yang dominan sebagai akuifer dengan produktivitas rendah.

\subsection{Status Daya Dukung Sumberdaya Air}

Pada penelitian ini, status daya dukung sumberdaya air (Cw) untuk tahun alokasi 2020 dan proyeksi alokasi 2030 dihitung dengan persamaan (Narulita dan Djuwansah, 2018):

$$
C w=W n / q p(t)
$$

dimana Wn adalah ketersediaan air dan $q p(t)$ adalah permintaan atau konsumsi air pada satuan waktu tertentu.

Hasil analisis daya dukung (Cw) memperlihatkan bahwa kuantitas sumberdaya air tahunan eksisting 2020 (Tabel 8) dan proyeksi 2030 (Tabel 9) sebesar 4,87 masih mencukupi atau memenuhi dalam penyediaan air untuk kebutuhan aktivitas di dalam Sub DAS (qp(t)). Keterbatasan ketersediaan air menurut daya dukung hanya dijumpai pada musim kemarau saja. Terlihat pada Tabel 8 dan 9, bulan Juni dan September dengan status neraca air surplus ternyata masih belum cukup memadai karena diklasifikasikan status daya dukung air $(\mathrm{Cw})$ yang kritis, meskipun belum sampai ke kelas defisit.

Pada musim hujan, sebagian besar air hujan yang jatuh akan menjadi limpasan dan kembali ke aliran sungai. Kecilnya air yang mengimbuh atau terinfiltrasi ke dalam tanah dikarenakan porositas dan permeabilitas atau kelulusan tanah terhadap air yang rendah, sehingga mudah mengalami penjenuhan dan berakibat menjadi run off di permukaan.

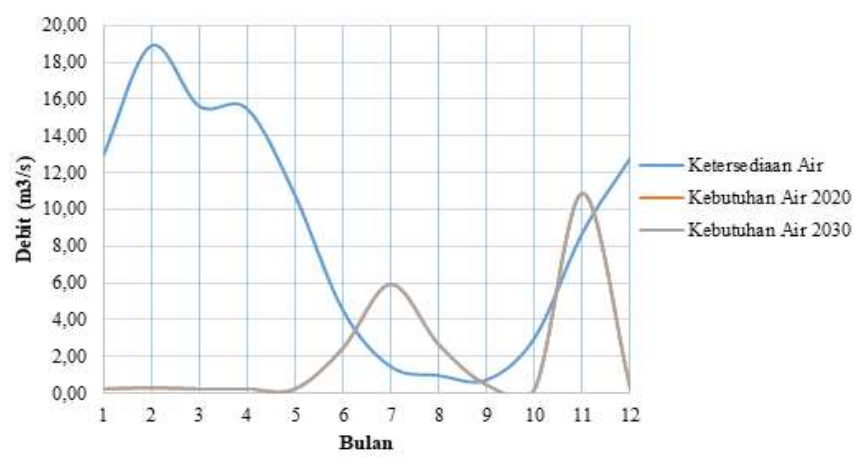

Gambar 2. Grafik Neraca Air Sub DAS Cisokan Hulu

Tabel 8. Penentuan Status Daya Dukung dan Indeks Kekritisan Air Sub DAS Cisokan Hulu 2020

\begin{tabular}{crrrcrccc}
\hline Bulan & $\sum$ Wn & $\sum$ qp(t) & Neraca Air & Status NA & Cw & Status Cw & $\begin{array}{c}\text { IKA } \\
\text { Ratio }\end{array}$ & $\begin{array}{c}\text { Status } \\
\text { IKA }\end{array}$ \\
\hline Jan & 12,93 & 0,19 & $\mathbf{1 2 , 7 4}$ & $\mathbf{S}$ & $\mathbf{6 8 , 0 3}$ & $\mathbf{T}$ & $1 \%$ & $\mathrm{BK}$ \\
Feb & 18,93 & 0,26 & $\mathbf{1 8 , 6 7}$ & $\mathbf{S}$ & $\mathbf{7 2 , 7 9}$ & $\mathbf{T}$ & $1 \%$ & $\mathrm{BK}$ \\
Mar & 15,63 & 0,19 & $\mathbf{1 5 , 4 4}$ & $\mathbf{S}$ & $\mathbf{8 2 , 2 4}$ & $\mathbf{T}$ & $1 \%$ & $\mathrm{BK}$ \\
Apr & 15,49 & 0,19 & $\mathbf{1 5 , 3 0}$ & $\mathbf{S}$ & $\mathbf{8 1 , 5 0}$ & $\mathbf{T}$ & $1 \%$ & $\mathrm{BK}$ \\
Mei & 10,77 & 0,19 & $\mathbf{1 0 , 5 8}$ & $\mathbf{S}$ & $\mathbf{5 6 , 6 6}$ & $\mathbf{S}$ & $2 \%$ & $\mathrm{BK}$ \\
Jun & 4,49 & 2,42 & $\mathbf{2 , 0 7}$ & $\mathbf{S}$ & $\mathbf{1 , 8 5}$ & $\mathbf{K}$ & $54 \%$ & $\mathrm{AK}$ \\
Jul & 1,41 & 5,90 & $\mathbf{- 4 , 4 9}$ & $\mathbf{D}$ & $\mathbf{0 , 2 4}$ & $\mathbf{D}$ & $420 \%$ & SK \\
Ags & 0,93 & 2,61 & $\mathbf{- 1 , 6 8}$ & $\mathbf{D}$ & $\mathbf{0 , 3 5}$ & $\mathbf{D}$ & $282 \%$ & SK \\
Sep & 0,69 & 0,42 & $\mathbf{0 , 2 7}$ & $\mathbf{S}$ & $\mathbf{1 , 6 3}$ & $\mathbf{K}$ & $61 \%$ & $\mathrm{AK}$ \\
Okt & 2,99 & 0,19 & $\mathbf{2 , 8 0}$ & $\mathbf{S}$ & $\mathbf{1 5 , 7 1}$ & $\mathbf{S}$ & $6 \%$ & $\mathrm{BK}$ \\
Nov & 8,73 & 10,85 & $\mathbf{- 2 , 1 2}$ & $\mathbf{D}$ & $\mathbf{0 , 8 0}$ & $\mathbf{D}$ & $124 \%$ & SK \\
Des & 12,81 & 0,20 & $\mathbf{1 2 , 6 1}$ & $\mathbf{S}$ & $\mathbf{6 4 , 0 3}$ & $\mathbf{T}$ & $2 \%$ & $\mathrm{BK}$ \\
\hline Total & 104,81 & 21,52 & $\mathbf{8 3 , 2 9}$ & $\mathbf{S}$ & $\mathbf{4 , 8 7}$ & $\mathbf{M}$ & $21 \%$ & $\mathrm{BK}$ \\
\hline
\end{tabular}

Keterangan: Status Cw : Status Daya Dukung Sumberdaya Air; T: Tinggi; S : Sedang; M :Memadai; K : Kritis; D : Defisit. IKA: Indeks Kekritisan Air; BK:Belum Kritis; AK: Akan Kritis; SK: Sangat Kritis (Sumber: Hasil Analisis, 2021) 
Tabel 9. Penentuan Status Daya Dukung Sumberdaya Air Sub DAS Cisokan 2030

\begin{tabular}{|c|c|c|c|c|c|c|c|c|}
\hline Bulan & $\sum \mathbf{W n}$ & $\sum q p(t)$ & Neraca Air & Status NA & Cw & Status Cw & $\begin{array}{c}\text { IKA } \\
\text { Ratio } \\
\end{array}$ & $\begin{array}{c}\text { Status } \\
\text { IKA }\end{array}$ \\
\hline Jan & 12,93 & 0,21 & 12,72 & $S$ & 61.55 & $S$ & $2 \%$ & BK \\
\hline Feb & 18,93 & 0,28 & 18,65 & $\mathbf{S}$ & 67.59 & $\mathrm{~T}$ & $1 \%$ & BK \\
\hline Mar & 15,63 & 0,21 & 15,42 & $S$ & 74.40 & $\mathbf{T}$ & $1 \%$ & BK \\
\hline Apr & 15,49 & 0,21 & 15,28 & $\mathbf{S}$ & 73.74 & $\mathrm{~T}$ & $1 \%$ & BK \\
\hline Mei & 10,77 & 0,21 & 10,56 & $S$ & 51.26 & $S$ & $2 \%$ & BK \\
\hline Jun & 4,49 & 2,44 & 2,05 & $S$ & 1.84 & K & $54 \%$ & AK \\
\hline Jul & 1,41 & 5,92 & $-4,51$ & D & 0.24 & D & $421 \%$ & SK \\
\hline Ags & 0,93 & 2,63 & $-1,70$ & D & 0.35 & D & $284 \%$ & SK \\
\hline Sep & 0,69 & 0,44 & 0,25 & $S$ & 1.56 & K & $64 \%$ & AK \\
\hline Okt & 2,99 & 0,21 & 2,78 & $S$ & 14.21 & $S$ & $7 \%$ & BK \\
\hline Nov & 8,73 & 10,87 & $-2,14$ & D & 0.80 & D & $125 \%$ & SK \\
\hline Des & 12,81 & 0,22 & 12,59 & $S$ & 58.20 & $S$ & $2 \%$ & BK \\
\hline Total & 104,81 & 21,54 & 83,27 & $S$ & 4.87 & M & $21 \%$ & $\mathrm{BK}$ \\
\hline
\end{tabular}

Keterangan: Status Cw : Status Daya Dukung Sumberdaya Air; T: Tinggi; S : Sedang; M :Memadai; K : Kritis; D : Defisit. IKA: Indeks Kekritisan Air; BK:Belum Kritis; AK: Akan Kritis; SK: Sangat Kritis (Sumber: Hasil Analisis, 2021)

\subsection{Indeks Kekritisan Air Sub DAS Cisokan Hulu}

Tingkat kekritisan air diketahui dari perbandingan jumlah kebutuhan air total dengan jumlah ketersediaan air, dengan perhitungan berdasarkan rumus sebagai berikut (Hatmoko et al., 2012):

$$
\operatorname{IKA}(\%)=(q p(t) / W n) \times 100
$$

dimana $q p(t)$ adalah permintaan atau konsumsi air pada satuan waktu tertentu $\left(\mathrm{m}^{3} / \mathrm{s}\right)$ dan $\mathrm{Wn}$ adalah ketersediaan air $\left(\mathrm{m}^{3} / \mathrm{s}\right)$.

Hasil analisis penentuan IKA Sub DAS Cisokan Hulu 2020 dan proyeksi 2030 ditampilkan dalam Tabel 8 dan Tabel 9. Penentuan nilai indeks kekritisan air disesuaikan dengan kriteria yang terdiri dari lima kelas mulai dari belum kritis, mendekati kritis, agak kritis, kritis dan sangat kritis. Hasil analisis Indeks Kekritisan Air antara tahun eksisting 2020 dan proyeksi 2030 menunjukan tidak terdapat perbedaan signifikan. Hal itu disebabkan oleh analisis neraca air yang juga tidak mengalami perubahan nilai yang signifikan. Periode musim hujan mulai Desember hingga Mei memperlihatkan nilai indeks terhadap kekritisan air yang sangat aman dan belum akan mengalami krisis dengan sisa air yang sangat melimpah. Namun, memasuki musim kemarau mulai dari bulan Juni hingga November dikhawatirkan timbul krisis air yang sangat berpengaruh. Terutama bulan Juni sebagai penggunaan air yang cukup besar sebagai inisiasi dimulainya musim tanam palawija.

Keadaan kekritisan air harus diantisipasi dengan memperhitungkan pemanfaatan terhadap sumberdaya air yang tersedia. Untuk area pemukiman di Sub DAS Cisokan Hulu, pemanenan air hujan untuk dimanfaatkan pada musim kemarau dapat mengurangi beban konsumsi air terhadap ketersediaan air. Akan tetapi bukan berarti pada saat kondisi air berlebih, eksploitasi terhadap sumberdaya air dapat dilegalkan. Harus diupayakan agar ekosistem tetap mampu melaksanakan kewajibannya dalam memberikan layanan sumberdaya air secara berkelanjutan.

\section{KESIMPULAN DAN SARAN}

\subsection{Kesimpulan}

Analisis ketersediaan air permukaan dengan debit andalan metode Weibull menghasilkan nilai ketersediaan tahunan sebesar $104,72 \mathrm{~m}^{3} / \mathrm{s}$. Total ketersediaan air tahunan dari aliran sungai Cisokan, PDAM, cadangan air tanah, mata air untuk tahun alokasi 2020 sebesar 104,81 m³.s. Kebutuhan air total sektor domestik pada tahun alokasi 2020 sebesar 21,52 m³ $/ \mathrm{s}$. Kebutuhan air 
sektor domestik pada proyeksi tahun alokasi 2030 sebesar $0,16 \mathrm{~m}^{3} / \mathrm{s}$, dengan asumsi kebutuhan untuk sektor lainnya sama besar, sehingga kebutuhan air total pada 2030 diperkirakan mengalami sedikit peningkatan menjadi $21,54 \mathrm{~m}^{3} / \mathrm{s}$. Analisis neraca air untuk tahun 2020 dan 2030 menunjukkan bahwa Sub DAS Cisokan Hulu secara dominan masih memiliki ketersediaan air yang cukup memadai (surplus), namun masih mengalami defisit pada bulan kering khususnya bulan Juli, Agustus dan November. Status daya dukung sumberdaya air (Cw) Sub DAS Cisokan Hulu secara umum masih memadai (Tinggi), namun pada puncak kemarau yaitu Juni hingga November, status daya dukung air menunjukkan nilai 1,84 (Kritis) hingga 0,24 (Defisit). Indeks kekritisan air secara umum masih aman (Belum Kritis), namun pada periode kemarau khususnya bulan Juli, Agustus, dan November menunjukkan nilai $125 \%$ hingga $421 \%$ (Sangat Kritis), sehingga dapat dipastikan menjadi permasalahan kelangkaan air, terutama bulan Juni dengan penggunaan air yang cukup besar sebagai inisiasi dimulai nya musim tanam palawija.

\subsection{Saran}

Saran yang dapat diberikan berdasarkan penelitian ini adalah perlu adanya update ketersediaan informasi data sekunder oleh instansi terkait, untuk mengakomodir riset mengenai kebutuhan data statistik. Selain itu perlu adanya riset mendalam untuk mengetahui nilai potensi cadangan air tanah dan juga nilai kebutuhan air aktual dari setiap sektoral. Sebaiknya hasil riset ini dijadikan acuan oleh seluruh stakeholder dalam mengalokasikan kebutuhan air sesuai dengan ketersediaannya. Sehingga ekosistem akan mampu berkelanjutan memberikan pelayanan penyediaan sumberdaya air secara langsung maupun tidak langsung kepada masyarakat di dalam wilayah Sub DAS Cisokan Hulu.

\section{DAFTAR PUSTAKA}

BPPN (Badan Perencanaan Pembangunan Nasional). 2006. Pedoman Kontruksi dan Bangunan. Jakarta. Direktorat Pengairan dan Irigasi.
BPS (Badan Pusat Statistik). 2012. Pedoman Penghitungan Proyeksi Penduduk dan Angkatan Kerja. Jakarta. Statistics Indonesia.

BSN (Badan Standarisasi Nasional). 2015. SNI 6738-2015. Perhitungan Debit Andalan Sungai dengan Kurva Durasi Debit. Jakarta. Badan Standarisasi Nasional.

Hatmoko, W., Radhika, S. A., Fauzi, M., Firmansyah, R., Solihah, R., dan Fathoni, A. 2012. Neraca ketersediaan dan kebutuhan air pada wilayah sungai di Indonesia. Laporan Akhir. Bandung (ID): Puslitbang Sumber Daya Air.

Kodoatie, R. J. 1996. Pengantar Hidrogeologi. Penerbit: Andi Offset. Yogyakarta.

Narulita, I dan Djuwansah, M. 2018. Kajian daya dukung sumberdaya air berdasarkan analisis ketersediaan dan kebutuhan sumberdaya air: studi kasus Daerah Aliran Sungai Cerucuk, Pulau Belitung. Jurnal Lingkungan dan Bencana Geologi, 9(2): 53-63.

Novita, S., Fauzi, M., dan Suprayogi, I. 2020. Analisis Kebutuhan Air Kabupaten Kampar. Selodang Mayang: Jurnal Ilmiah Badan Perencanaan Pembangunan Daerah Kabupaten Indragiri Hilir, 6(3): 209-220.

Nurrochmad, I. F. 2003. Optimasi pemanfaatan air irigasi Bendung Cisokan pada Daerah Irigasi Cihea Cisokan Kabupaten Cianjur. [Doctoral dissertation]. Yogyakarta. Universitas Gadjah Mada.

Purwanto, M. Y. J. 1995. Water demand for industry, village, and city. In Labotory seminar on Water Demand and Developing Country. The University of Tokyo. Japan.

Rejekiningrum, P. 2014. Identifikasi kekritisan air untuk perencanaan penggunaan air agar tercapai ketahanan air di DAS Bengawan Solo. In Seminar Nasional FMIPA-UT (Vol. 23, pp. 170-184). 
Tumiar, K.M., Rosadi, R.B., Karyanto, A. 2012. Waspodo R.S.B. 2015. Eksplorasi Potensi Air Evaluasi Metode Penman-Mointeith dalam Tanah Pada Kawasan Industri Air Mineral menduga Laju Evaprotranspirai (ETo) di Dalam Kemasan, Cemplang Bogor. Jurnal Daratan Rendah Provinsi Lampung, Keteknikan Pertanian, 3 (2), 137-144. Indonesia. Jurnal Keteknikan Pertanian, 26 (6): 121-128. 